\title{
The behavioral approach to study rural youth problems
}

\author{
Riyaz Niyazovich Masalimov \\ Faculty of the Humanities and Social Sciences, Birsk Branch of Bashkir State University, Birsk, Russia
}

Email address:

n.empire@mail.ru

\section{To cite this article:}

Riyaz Niyazovich Masalimov. The Behavioral Approach to Study Rural Youth Problems. Journal of Human Resource Management. Vol. 2, No. 4, 2014, pp. 76-80. doi: 10.11648/j.jhrm.20140204.12

\begin{abstract}
In the article the necessity of the behavioral approach to study rural youth problems of Republic of Bashkortostan is grounding. An analysis of social and economical development of a rural region in 2008-2012 is presented. The negative dynamics of economical indices of the majority of rural territories of Republic causes the considerable deterioration of social components. Using the behavioral approach to study the agrarian sphere permits to provide the importance of behavioral factors in the sustainable development of rural territories. Rural youth is a reproductive foundation and strategic reserves of the sustainable development of agrarian sphere. The role of social factors in the achievement of effectiveness of agricultural production is considered.
\end{abstract}

Keywords: The Agrarian Sphere, the Sustainable Development, Behavioral Economics, Post-Modernism, Rural Youth

\section{Introduction}

The necessity of the behavioral approach to study rural youth problems in our region - Republic of Bashkortostan - is obvious. Modern social and economic anthropology takes into consideration the grown dangers and risks caused by introduction of new techniques as well as by the increased natural disasters. In social and cultural analysis of rural youth problems, particularly in studying the processes of the preparation for agricultural work, it is necessary to apply to so called "extraordinary anthropology" [5]. This newly-made discipline is intended for study diverse forms of existence approaching to limits of human life, and even getting over - penetrating into its demoniacal, feral, machine aspects.

\section{The Necessity and Behavioral Aspects of Preparation for the Agricultural Work Management}

The Russian villagers and their agrarian work become the main indices of changes in behavior and psychology of young rural workers. Altogether, a man in the center of agricultural production becomes more valuable during the harvest time which implies extreme labor conditions.

The behaviorist knowledge in educational process of attaining the agricultural managers will also be our further study. To take into account the psychological characteristics, it is important that a teacher knows the specifics of the student's personality, his interests, skills, character and temperament and his overall attitude towards learning. It is necessary that the teacher had some psycho-pedagogical culture, i.e. a general background of psycho-pedagogical knowledge, to be able to find the appropriate work processes that ultimately may enhance the effects of pedagogical influence on his disciples.

Without a proper psychological culture, the teacher will incomparably spend much more efforts and will, undoubtedly, get more modest results.

Practice shows that, by mainly focusing on promoting subjects, finding and applying effective methods of work, teachers often omit from their teaching field the psychological aspect of this process. Many of them encounter difficulties in determining age-specific peculiarities, limited to features such as: active or passive student, read or unread, industrious or lazy, or capitalizing on special characteristics of students that stand out either by success or by conflict behavior. The achievements in science are often unknown or overlooked by virtue of conservatism that exists in education and a resisting position against new and progressive ideas. Experience has shown that obtaining superior results by teachers is largely due to accounting knowledge and respect of future managers' psychological peculiarities, therefore we will focus on the peculiarities of the structure of volitional 
qualities of managers, many of which are formed in the their training - the main pillar in managerial activity is the will.

\section{Theory of "Behavioral Economics" for the Post-Modern Agriculture}

The conception of "Behavioral Economics" "Economics from the point of view of behavior of the producers and consumers" - is now the most perspective direction of economical theory. Scientific publications dedicated to investigation the different behaviorist factors of sustainable development of country-side have been appeared abroad recently. In our country, meanwhile, the problems of behavioral economics concerning the agrarian sphere were until not considered. All the more, it concerns the behavioral factors of agricultural economy and rural territories.

The behavioral economics at the methodological aspect considers the social and psychological particularity of human perception, mind and behavioral activity. Registration of these factors allows to improve really understanding ability of economical science, and to make the model constructions adequate to real economic situations.

It is necessary to emphasize in post-modernistic epoch a man really becomes in focus of the reproduction process. Present thesis has been most brightly reflected in enormous growth of popularity of a research theme "A Man and His Labor Activities". In particular, in 90-s of the XX century have been appeared theories on endogen economical growth within there a key factor would be the human capital $[16,18,21]$. At the beginning of the XXI century psychological theories of labor and capital started to develop, and a new scientific trend of "behavioral economics" was widely spread $[4,9]$. The essence of these theories is a man and his labor as a source of new ideas and innovations as well as key components of a stable development of the economic sphere.

An agrarian worker, actually, involved in extreme labor at set seasons can't help acting rationally. Nevertheless, our research proves that he has to rely on his intuition, biological instincts and also turns to his ancestors' experience which is, in fact, traditions and national culture.

Undoubtedly, there is also a skeptical approach to the post-modernism phenomenon in the non-material spheres of the society. By way of the illustration of the above mentioned criticism we can quote the famous post-modern author Victor Pelevin: "Post-modernism is making a doll's doll being a doll yourself" [15].

Meanwhile it ought to be stated that nowadays certain researchers still prefer to use the categories of materiality of economics unlike the representatives of "behavioralism" and "mentalism". In this case we can give an example of the economical behavior which is always determined by material things, artifacts that is property relations on the land market and other "market facilities".

\section{What does the Sustainable Development of the Agrarian Sphere in Russia Depend on}

\subsection{The Necessity of Orientation to a Model of Sustainable Development}

The problems of elaboration of the strategy of sustainable development of the agrarian sphere are now urgent problems in economical studies. At the worldwide level the strategy of transition to sustainable development of the agrarian sphere was declared at the UN Conference on environment and development in Rio de Janeiro (1992). Comprehension of the problems was reflected in a number of international acts, including resolutions of the session of FAO (Rome, 1996), some proceedings of the World Bank (January, 2000), documents of World Summit on sustainable development (RSA, 2002), European Presidents' Conference on innovations and clusters (Stockholm, 2006), UN Conference (Rio de Janeiro, 2012).

According to report of the UN International Commission on the environment and development (G.H. Brundtland), "our common future", "sustainable and permanent development is not an invariable status of harmony, but rather a process of changes in that volumes of exploitation of resources, trends of capital investments, orientations of technical development will be coordinated by the present and future needs and requirements" [7, p. 8].

\subsection{Rural Territories}

By Russian terminology rural territories are determined as "territories of rural settlements (may be one or several, with common local self-ruling, realizing directly, as well by elective bodies) and other inter-settlement territories (territories lying outside borders of settlements)" [10]. According to definition of European Council and OESD rural territories are "inner and littoral areas including small towns and villages serve as an agricultural and forest preserves or settling territories with aquaculture and fishing, opportunities for economical and social activities, relaxation and leisure" [19]. Proceeding from criteria of these international organizations, rural areas (or rural territories) are the overwhelming majority of municipal districts of Russian Federation.

The sustainable development of rural territories needs in the elaboration of a strategy ensuring the solution of problems emerging directly in municipal level. The orientation to a model of sustainable development must be aimed at the optimal combination of economical and social factors determining directly the effective functioning of rural territories $[12,13]$.

\subsection{Imperfection of Native Methodology}

The scientific elaborations dedicated to forming the 
strategies of the rural areas development on the regional level are not presented widely enough by the native researchers; they could facilitate to plan a balanced functioning of the productive and social spheres and to determine the possible conditions of stable growth of the agriculture. Adopted by the Government of Russian Federation Conception of special aim program "The Sustainable Development of Rural Territories of Russian Federation in 2014-2017 and till 2020" makes for an elaboration of new methodical approaches and propositions directed to planning the functioning of agrarian organizations on the immediately municipal level. The disproportions of development of rural municipal territories in pre-reform period were successfully smoothed over by directive methods, but under the conditions of modern agriculture production on the regional level it is necessary to use a differentiation approach permitting to take into account the individual particularities of functioning of rural territories and settlements.

The imperfection of native methodology of the strategic planning and forecasting of the development of rural territories on the sub-regional (municipal) level, the absence of system approach to study the priority development of rural territories summons the necessity of the permanent improving of methodic approaches to investigation this important problem. Nobel Prize laureate on economics Gunnar Myrdal truly emphasized: "the result of the struggle for sustainable lasting development will be obtained just in the agrarian sphere" [6].

\section{Using the Behavioral Approach}

\subsection{What Can the Behavioral Approach More}

In our opinion using behavioral approach as a modern instrument of scientific investigations could permit to effectively plan the strategy of sustainable development of agrarian sphere on different hierarchical level of management, including on the level of rural territories.

In a number of publications it is emphasized that most of the elaborated econometrical models actually fail to calculate the significant correlation of economical growth and human capital both in the time and in the inter-state spheres. Thus, it is stated that the considerable growth of the educational potential level of the population of the developing countries from 1960 to 1985 hasn't, practically, affected the tempo of their economic development [20].

A conclusion is also made that the role of the human factor in achieving the dynamic development of the economic sphere is very much exaggerated. It also shown that in modeling constructions the feedback hasn't been taken into consideration that is: the developed countries are actually increasing their expenditures on education and accumulating the human capital [17]. Besides, it is stated that the considerable amount of the educational capital accumulated by the population can affect the indices of the economic growth but very little, unless it is largely involved in the productive process provided that the unemployment level is high and the qualified labor-power is used ineffectively. At the same time it is emphasized that the lack of certain categories of workers can be filled up by way of stimulating external labor migration.

Using the behavioral approach to study the agriculture sphere functioning permits to pick out essential role of behavior factors in sustainable development of rural territories. First of all, it is necessary to note the patent absence of human resources for the reproduction of agriculture in the Russian Federation. The summarize of the world experience of scientific researches shows that rural youth as a specific social demographic section is a latent resource for development of the agrarian sphere and the strategic reserve for the reproduction of manpower in agrarian organizations.

\subsection{Influence of Negative Circumstances}

One of the main problems in our country is the diminution of numbers engaged in agriculture including the skilled young agrarian workers migrating into towns and cities. Thus, the numbers of rural population in the Republic Bashkortostan decreased to 48.7 thousand people in 2005, and made up 1592.0 thousand total in 2012 [11]. Numbers of the rural population younger of the able-bodied age in Republic in the same period (2005-2012) have decreased to 17.4 thousand. This decrease is at first bond up with the unwillingness to work in rural area, with the migration from the rural territories into cities and towns of Republic. The investigations carried out by ourselves is correlated to the data of the monitoring realized by Dr of sociology Boyak T.N., according to her only $26 \%$ of rural youth are satisfied to some extent by their material position [1, p. 183]. In addition, the more difficult social economic conditions than in towns have an influence on the way of living of the rural youth.

\subsection{The Rural Territories are Given up...}

Our analysis of the contemporary status of the rural territories of Republic Bashkortostan allows concluding that the social and economic position of majority of municipal units of our region is not stable, and that many of rural municipalities are developing disproportionally. In accordance with the data of Territorial body of Federal Statistics Service on RB in 2012 lands under cultivation were curtailed to 137.0 thousand ha (6\%) against 2008, including sowing areas of food grains reduced to 111.0 thousand ha $(8 \%)$ [11]. In the recent five years the cattle population has declined to 128.0 thousand. or to $21 \%$, including 33.0 thousand cows (15\%).

Since 2008 the negative dynamics of production of majority of agriculture produce kinds in our region. Thus, in period from 2008 to 2012 volumes of grain production were curtailed to $2861000 \mathrm{t}$, or to $63 \%$, volumes of production of sugar-beet - to $172000 \mathrm{t}(16 \%)$, potatoes to $528000 \mathrm{t}(34 \%)$, vegetables - to $54000 \mathrm{t}(16 \%)$. In 
same period volumes of milk production curtailed to $86000 \mathrm{t}(14 \%)$, wool production - to $4 \mathrm{t}(11 \%)$, honey production - to $892 \mathrm{t}(62 \%)$.

In conditions of joining to WTO and economic and commercial sanctions because of the Ukraine, the decrease of our own production is not acceptable. Meanwhile, the level of self-providing of the population of the Republic with meat dropped from $85 \%$ in 2008 , to $72 \%$ in 2012 , with vegetables - from $81 \%$ in 2008 to $70 \%$ in 2012, with potatoes - from $100 \%$ to $84 \%$.

\subsection{A Considerable Deterioration of the Social Sector}

Actually, the state of agrarian production directly affects the functioning of the social sphere and the infrastructure of rural territories. It is necessary to state that the regressive dynamics of the indices of the majority of the rural territories was reflected in a considerable deterioration of the social sector of rural areas.

In the period from 2008 to 2012 the number of preschool institutions decreased by 208 kindergartens, state and municipal comprehensive institutions - by 589 , culture centers - 134, public libraries - by 30 . In the National Health sphere the number of nurses decreased by 0.5 thousand, the number of hospital beds decreased by 1.2 thousand.

\subsection{Youth Abandoning Rural Territories}

In accordance with the data of Territorial body of Federal Statistics Service on RB in the period from 2005 to 2012 the number of the agrarian workers decreased by 191 thousand people, which is, by $14 \%$ [11]. As the researchers Nefyodova T.G. and Pallot J. emphasized, that "those who are eager to succeed escape the rural sphere thus causing the low level of opportunities and claims of the local population" [8, p. 104].

The high level of unemployment in different branches of agriculture is caused by low wages and poor working conditions. As Dr of sociology Nechiporenko O.V. states, "everywhere the rural workers face the same set of problems: unemployment, sharp decrease of the financial income, ousting of the labor resources into the sphere of private farms which have become the main factor of surviving of the rural population" $[9$, p. 58].

These tendencies have a negative effect on the development of agriculture. As a result, the depopulation of rural territories, the decrease of the amount of agrarian worker causes reduction and taking out of economic circulation the land resources. Further, by nature, every person aims to be successful and accepted into the society, does his best to realize his potential, but owing to his low professional culture and high competition in welldeveloped branches of economy a young agrarian worker feels diminished which has a negative effect on his selfesteem. And the real self-esteem of a young rural worker, actually, very much influences his entire further career and his general world-vision in future [14].

\section{Conclusion}

It ought to be emphasized that in the crisis period of the development of state the degree of uncertainty, instability and the manifestation of negative psychological effects increases. At present the young generation of rural territories particularly need attention for in the tine of great changes they feel psychological discomfort and very often complete depression; they are disillusioned in the atmosphere of general confusion, moral degradation, dissoluteness, indifference and passiveness [5].

Under modern conditions of the social and economic reforms in rural section the elaboration of new scientific approaches concerning the reproductive ground of sustainable development of rural territories is necessary. The behavioral factors are directly bound with the possibilities, motivations of survival of every person living in a rural area.

In our opinion, the elaboration of the conception of sustainable development of rural territories of RB must be based on introducing of the effective management decisions and practical recommendations which are sure to raise the economic effectiveness of the agricultural production. Undoubtedly, the increase of investments into the human resource at the expense of the effectiveness of agrarian production will be supplemented with the social effect $[2,3]$.

It is important to state that defining the priority directions of functioning rural territories on the basis of behavioral approach enables us to formulate precise principles of effective social and economic development of municipal territories of Republic of Bashkortostan. Increasing agricultural production volumes will determine potential possibilities of involving supplementary labor resources into the rural areas and create working places in agrarian units and state budget institutions. The increase of profit of rural producers will help to create positive factors for the income of agrarian workers to grow, for the development of the social sphere, and finally, for the raising the life level of rural population.

\section{References}

[1] Boyak T.N. Osobennosti kul'tury sovremennoi sel'skoy molodyozhi (Pecularities of Culture of Modern Rural Youth) // Gumanitarnyi vector. Seria: Filosofiya, kul'turologiya. 2012. - No. 3. - P. 180-186.

[2] Gusmanov U.G., Gusmanov R.U., Stovba Ye.V. Povysheniye ekonomicheskoy effektivnosti agrarnogo proizvodstva kak vazhneyshiy factor razvitiya sotsial'noy sfery sel'skikh territoriy (The Increase of the Agriculture Production Economic Effectiveness as the Most Important Factor of Development of the Rural Territories Social Sphere) // Agroprodoval'stvennaya politika Rossii. - 2013. - No. 12. - P. 87-93.

[3] Gusmanov U.G., Gusmanov R.U., Stovba Ye.V. Optimizatsiya proizvodstvennoy struktury agroorganizatsiy - osnova razvitiya sotsial'noy sfery sel'skikh territoriy (Optimization of the Agrarian Units Productive Structure is a Basis of the Development of Rural Territories Social Sphere) // Vestnik Altayskogo gosudarstvennogo agrarnogo universiteta. - 2013. - No. 8. -P. 133-138. 
[4] Masalimov R.N., Masalimov I.R. Ponyatiye o bikhevioral'noy ekonomike (The Concept of Behavioral Economics) // Chelovek i mir: Vtoryie Chudinovskiye chteniya. - Ufa-Birsk, 2009. - P. 152-155.

[5] Masalimov R.N., Stovba Ye. V. Sotsiyal'nyie I psichologicheskiye problemy molodyozhi sel'skikh territoriy (Social and Psychological Problems of the Rural Territories Youth) // Sovremennyie issledovaniya sotsial'nych problem (Elektronnyi nauchnyi zhurnal). - 2012. - No. 1. $\quad$ - $\quad$ P. 374-307 (URL: http://sisp.nkras.ru/issues/2012/1/stovba.pdf).

[6] Murdal G. Sovremennyie problemy "tret'ego mira" (Modern Problems of the "Third World"). - M.: Progress, 1972 [Cit. on: Ustoychivoye razvitiye sel'skikh terrotoriy (The Sustainable Development of Rural Territories) / Ed. by Bautin V.M. - M., 2004. - P. 12].

[7] Nashe obshcheye budushcheye: Doklad Mezhdunarodnoy komissii po okryzhayushchey srede b razvitiyu (Our Common Future: Report of International Comission on the Environment and Development). - M.: Progress, 1989. $376 \mathrm{p}$.

[8] Nefyodova T.G., Pallot J. Neizvestnoye sel'skoye khozyaistvo, ili zachem nuzhna korova?(Unknown Agriculture, or why needs a man a cow?). - M.: Novoye izdatel'stvo, 2006. - 320p

[9] Nechiporenko O.V. Sel'skoye naseleniye I reformy agrarnoy sfery: Adaptatsiya ili degradatsiya? (The Rural Population and the Reforms in the Agrarian Sphere: Adaptation or Degradation?) // Sotsiologicheskiye issledovaniya. - 2009. 2009. - No. 6. - P. 57-66.

[10] Rasporyazheniye Pravitel'stva RF ot 8.11.2012 No. 2071-r "O Kontseptsii federal'noy zelevoy programmy "Ustoychivoye razvitie sel'skikh terrotoriy na 2014-2017 gody i na period do 2020 goda" (The Order of RF Government 11/08/2012 No. 2071-r "Conception of Special Program "Sustainable Development of Rural Territories 2014-2017 and in period till 2020" (URL: http://www.garant.ru/products/ipo/prime/doc/70155950).

[11] Sel'skoye khozyaistvo, okhota I lesovostvo Respubliki Bashkortostan: statisticheskiy sbornik (Agriculture, Hunting and Forestry: Statistical Collection). - Ufa: Bashkortostanstat, 2013. - 190 p.
[12] Stovba Ye.V. Optimizatsiya proizvodstvennoy struktury agroorganiztatsiy kak sostavnaya chast' modelirovaniya razvitiya sel'skikh territoriy regiona (Optimization of the Agrarian Units Production Structure as a Component of the Modeling of Development of Rural Territories of a Region) // V mire nauchnykh otkrytiy. - 2011. - No. 10.2. - P. 1029-1041.

[13] Stovba Ye.V. Modelirovaniye stsenariyev razvitiya agroprodovolstvennoy sfery sel'skikh territoriy regiona $\mathrm{v}$ usloviyakh vstupleniya Rossii v VTO (Modeling the Scenarios of Agriculture Sphere Development of Rural Territories of a Region under the Conditions of Russia Joining into WTO) // V mire nauchnykh otkrytiy. - 2012. N0. 10.2. - P. 251-271.

[14] Stovba Ye.V., Masalimov R.N., Stovba A.V. Sel'skaya molodyozh' v usloviakh modernisatsii agrarnoy ekonomiki (na materialakh Respubliki Bashkortostan) (Rural Youth in the Conditions of Modernization of Agrarian Economy (On Materials of Republic of Bashkortostan) // Sovremennyie issledovaniya sotsial'nych problem (Elektronnyi nauchnyi zhurnal). - 2014. - No. 2. - P. 14 (URL: http://journals.org/index.php/sisp/article/view/2201414/pdf_504).

[15] Yarzhembovskiy S. Postmodern kak gebefrenicheckiy sindrom (The Post- Modern as a hebephrenic syndrome) // Zvezda. -2010. - No 8. - P. 206.

[16] Benhabib J., Spiegel M. The Role of Human Capital in Economic Development: Evidence from Aggregate CrossCountry Data // Journal of Monetary Economics. - 1994. Vol. 34. - No 2.

[17] Bils M., Klenow P. Does Schooling Cause Growth? // American Economic Review. - 2000. - Vol. 90. - No 5.

[18] Lucas R. On the Mechanics of Economic Development // Journal of Monetary Economics. - 1988. - Vol. 22. - No 1.

[19] OECD-Prüfbericht zur Politik für ländliche Räume. Deutschland / Organisation für wirtschaftliche Zusammenarbeit und Entwicklung, 2007.

[20] Pritchett L. Where Has All the Education Gone? // World Bank Economic Review. - 2001. - Vol. 15. - No 3.

[21] Romer P. Endogeneous Technological Change // Journal of Political Economy. - 1990. - Vol. 98. - No 5.

[22] Rubinstein A. Discussion of «Behavioral Economics»// www.arielrubinstein.tau.ac.il/papers/76.pdf. 